\title{
ÚJVIDÉKI EGYETEM \\ MAGYAR TANNYELVŰ TANÍTÓKÉPZŐ KAR
}

Újvidéki Egyetem Magyar Tannyelvű Tanítóképző Kar

Cím: Szabadka, Strossmayer utca 11.

Honlap: http://www.magister.uns.ac.rs

E-mail: office@magister.uns.ac.rs

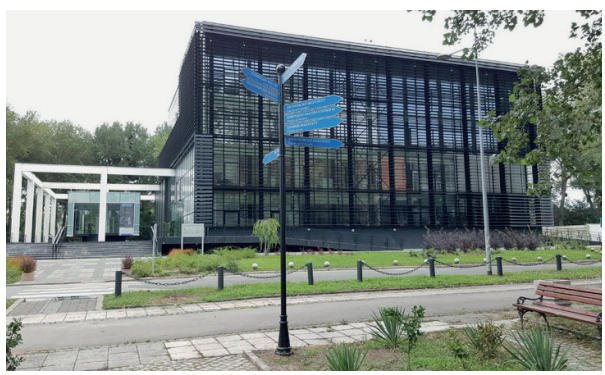

Több mint 50000 hallgatójával és 5000 dolgozójával az Újvidéki Egyetem az egyik legnagyobb oktatási és tudományos központ Szerbiában. Az Újvidéki Egyetem fejlett tudományos infrastruktúrával és jelentős innovációs potenciállal rendelkezik. A központi könyvtár, valamint a karok és intézetek könyvtárai minden mérvadó tudományterületet lefedő, gazdag könyvállománnyal rendelkeznek, illetve lehetővé teszik a nagy elektronikus adatbázisokhoz való hozzáférést is.

Az Újvidéki Egyetem székhelye Újvidéken, a Duna-parti központi kampuszban található, a Péterváradi vár, illetve a régi városközpont közvetlen közelében. Ugyanitt van a Bölcsészettudományi Kar, a Mezőgazdasági Kar, a Természettudományi Kar, a Jogtudományi Kar, a Műszaki Tudományok Kara, a Technológiai Kar, a Testnevelési Kar, az Élelmiszer-technológiai Intézet, valamint a szabadkai Közgazdasági Kar kihelyezett tagozata is. Gyakorlati okokból az Orvostudományi Kar, a Művészeti Akadémia, illetve az Alföldi Erdészet- és Környezetfejlesztési Kutatóintézet a város más pontjain helyezkednek el.

A Pedagógiai Kar Zomborban, míg a Mihajlo Pupin Műszaki Kar Nagybecskereken található. Szabadkán a Magyar Tannyelvű Tanítóképző Karon kívül a Közgazdasági Kar, valamint az Építőmérnöki Kar múködik.

Az Újvidéki Egyetem keretein belül a Magyar Tannyelvű Tanítóképző Kar különleges helyet foglal el, hiszen lehetővé teszi a Szerbiában élő magyar közösség tagjai számára, hogy az európai standardoknak megfelelően valósíthassák meg kisebbségi jogaikat a tudomány, az oktatás és a kultúra területén, ezenkívül hozzájárul a régió jószomszédi viszonyainak fejlődéséhez is.

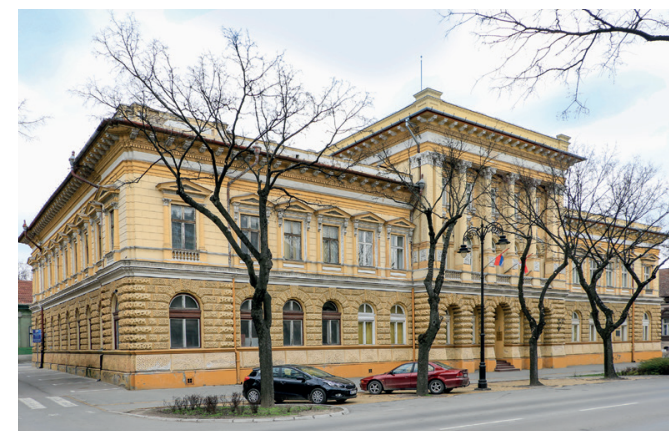




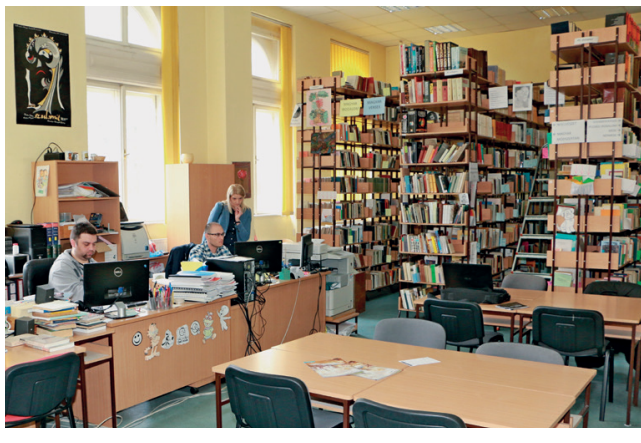

Az Újvidéki Egyetem nagy egyetemi közösségének keretében múködő 14 kar közül a szabadkai Magyar Tannyelvü Tanítóképző Kar a legfiatalabb, ahol kizárólag magyar nyelven folyik az oktatás. 2006-ban alakult meg, amikor az új intézmény új könyvtárat is kapott.

A kar könyvtára nagyjából 3000 könyvvel kezdte meg múködését. Állományunk azóta mintegy 30 ezer könyvtári egységgel rendelkezik. A könyvtár megalapításának alapvető célja volt a legnagyobb magyar nyelvű pedagógiai és módszertani jellegű szakirodalmi bázis létrehozása a Vajdaságban.

Egyetemi tanulmányait 2004 és 2009 között végezte az Újvidéki Egyetemen, ahol osztálytanító mesterdiplomát szerzett. 2008-2009-ben a horgosi Október 10. Általános Iskolában dolgozott. 2009 óta az Újvidéki Egyetem Magyar Tannyelvű Tanítóképző Kar könyvtárának vezetője. 